PERAET 2021

International Scientific Conference «PERISHABLE AND ETERNAL: Mythologies and Social Technologies of Digital Civilization-2021»

\title{
VIRAL INFORMATION PANDEMIC AS A PROBLEM OF MODERN CIVILIZATION
}

\author{
Olga N. Ivanishcheva (a)*, Helge Räihä (b), Christina von Post (c) \\ *Corresponding author
}

(a) Murmansk Artic State University, Murmansk, Russian Federation, oivanishcheva@gmail.com

(b) Örebro University, Sweden, Helge.Raiha@oru.se

(c) Örebro University, Sweden, Christina.Vonpost@oru.se

\begin{abstract}
The purpose of the present work is to analyze the reasons for the transformation of information into a viral one (based on the material of the regional mass media of the Murmansk region, Russia). The research material is the media and social networks of the Murmansk region. The choice of regional sources is due to their vulnerability and dependence on the financial capabilities of editorial offices and a limited audience. The research methods in the work are the method of continuous sampling, discourse and content analysis, as well as an integrated and structural approach. It is shown that the reasons for which information becomes viral are its content and ways of distribution. Currently, the so-called "shuttle path" is becoming important, according to which social networks are sources of information for traditional media, whose opinions from publications are then returned to social networks, where users discuss the problem, including in the form of comments on the publication on the Internet. Another important reason why information becomes viral is its content, that is, its easy digestibility and recognition. At the same time, the virality of information increases, which becomes so interesting for media users that they want to share it. In this way, the audience's trust in traditional media is formed. Field of application of the results. The research results can be applied in the practical activities of journalists, PR-technologists, bloggers.
\end{abstract}

2357-1330 @ 2021 Published by European Publisher.

Keywords: Fakes, social networks, viral information 


\section{Introduction}

The combination of the problems of information dissemination and the viral way of its dissemination in an era when the world is being shaken by a pandemic of a monstrous disease, creates a special perspective and special urgency of the problem, which can be conventionally called a virus pandemic.

\section{Problem Statement}

In a separate communication space, the issues that have been of interest to researchers of communication theory for many years, firstly, have become even more in demand, and secondly, they have found even more points of contact and/or intersection. This applies to the following questions.

First, how, in a dispersed audience (space of divided people) during a period of forced lack of communication during a pandemic, for example, can the problem of disinformation be solved? If we do not know how true the information is, whether there are elements of manipulation of our consciousness, then how will we find out the truth? We are scattered, we are in a state of isolated space, but in parallel we are constantly in virtual space, where we are offered a constant, almost infinite, choice between true and untrue. Secondly, the very concept of "disinformation" (fake, rumors, gossip) is still terminologically vague. It is clear that rumors and fakes are essentially unverified data, but we believe them, or rather, we want to believe. Currently, the sources of unverified information are mainly social networks. The modern media also draw their information from the same source. The problem of disinformation became especially acute during the COVID-19 pandemic, which determined the potentially catastrophic consequences for communication in society as a result of distrust of the media (Flew, 2021; Kolokytha \& Rozgonyi, 2021; Richter, 2021).

At the present stage of the development of communication technologies, it is relevant to study the problems of viral information, which is understood as information that has the ability to self-replicate and to be repeated many times in different versions, up to a complete loss of meaning or acquiring the opposite meaning (Dabezha, 2019, p. 30). In this regard, it is necessary to investigate this phenomenon, correlating it with already known phenomena.

\section{Research Questions}

Our work is devoted to the discussion of the following research questions: what does the virality of information depend on and why does it become viral? is there a relationship between negative/positive news and its transformation into viral information?

\section{Purpose of the Study}

The purpose of the work is to analyze the reasons for the transformation of information into a viral one (based on the material of the regional mass media of the Murmansk region, Russia). 


\section{Research Methods}

The research methods in the work are the method of continuous sampling, discourse and content analysis, as well as an integrated and structural approach.

The research material is the media and social networks of the Murmansk region. The choice of regional sources is due to their greater vulnerability and dependence on the financial capabilities of editorial offices and a limited audience compared to the federal media (Tretyakova et al., 2019).

\section{Findings}

\section{Social networks and their role in shaping the agenda}

The problem of the functioning of social media is a constant source of discussion in the field of the theory of journalism. Over the past decade, the topical issues have become questions about the identity of users of social networks (Jenzen et al., 2021), about pluralism in the media and its regulation (Schlosberg \& Freedman, 2020). There is even research on the emotional component of contemporary journalism (Huxford \& Hopper, 2020). Research on the use of social networks to communicate with ordinary citizens, in particular among politicians, is still relevant (Larsson, 2020).

In the scientific and educational literature, at forums and congresses of journalists in recent years, the issue of how to recognize fakes has been discussed, it is noted that in the modern world the difference between truth and propaganda is especially blurred, which is why it is so difficult for the media to earn the trust of users (Reily, 2020). Fake news creates a sense of excitement, which is why they are so readily believed. And such Internet fakes are scattered on social networks like a virus (Nord-News.RU, 2018).

Murmansk mass media create more than $60 \%$ of news on the basis of materials from press releases of regional and municipal governments, law enforcement agencies and various special services. Regional television media more often than news agencies publish unique content due to the large number of reports from the scene. $1 / 10$ of the content is occupied by articles and videos about the activities of various companies that have a lot of weight in the Murmansk region, as they invest large sums of money in the development of the region and improve the quality of production of their services. Such companies include, for example, Kolskaya GMK (Kola MMC), PhosAgro and others. The rest of the content in the media of the Murmansk region is formed on the basis of social media posts, in which information about an event or incident may appear earlier than in official sources. Such information requires careful verification before publication, as the source often suffers from "source amnesia". Journalists, as a rule, clarify information in the official press services of companies, special services and various departments.

However, not all media outlets in the Murmansk region are cautious when publishing questionable content. For example, the SeverPost news agency was more often than others accused of publishing unverified information, as well as distorting information from press releases of official media.

\section{The path of spreading viral information as a way to gain the trust of media users}

In a situation of decreasing confidence in the media, journalists try to turn more often to the socalled "people's sources of information" (Nigmatullina, 2021). For their part, the authors of popular and widely discussed posts are often ready to go into open dialogue with their audience, openly express their 
opinions. The Internet audience especially trusts the authors of posts who act under their real name, and do not hide under a pseudonym and an "avatar".

Many municipal governments, following current trends, have posted their groups on social networks and opened channels with official information in the Telegram messenger to make access to news from trusted sources easier and more convenient for most users. Posts from VKontakte and other social networks and messengers in news stories are used to one degree or another by all mass media in the Murmansk region. For example, the Bi-Port news agency uses its VKontakte social network group to post photo collages from some events and meetings, as well as publish notes that were not included in the news feed for one reason or another. This news agency can be classified as a news aggregator. Although B-Port creates unique content from time to time, more than $70 \%$ of the news feed is occupied by rewrites of other people's messages and press releases. It is important to note that Bi-Port journalists always indicate the source of the rewritten and published news. Information is always checked for authenticity before publication, unlike the SeverPost news agency, which also fits the definition of a news aggregator.

Thus, at the moment, viral information has two streams of distribution: if earlier it was spread through social networks, through posts and reposts of users, now it has moved to the professional journalistic environment. In addition, this distribution path increases the virality of information, that is, its ability to increase the speed with which one wants to share such news. It can be argued that not only the interactivity of the content makes it potentially viral (Dabezha, 2019, p. 31), but also the passage of information through the filter of traditional media.

Content of information as the root cause of its virality

It has been noticed that easy-to-understand ideas are easier for users of information to digest and generate more trust and positive feelings.

The COVID-19 pandemic has become not only a test of strength, but also an incentive for scientific research in various fields, including in the field of journalism (see, for example: Flew, 2021, p. 11; Kazun \& Kazun, 2020, p. 288). After all, it is through the coverage of information materials regarding the state of affairs with the COVID-19 coronavirus pandemic in the world and in Russia that the domestic audience learns the latest, fresh news, receiving the necessary and useful information for their own safety and prevention.

Discussing the content of publications and the dependence of the ability of information to disseminate on it, we analyzed publications about COVID-19 in the municipal newspaper Murmanskiy Vestnik.

From the article "V Rossii sozdali lekarstvo ot koronavirusa"[A cure for coronavirus has been created in Russia], we learn that there is a treatment regimen for coronavirus infection based on the antimalarial drug mefloquine, which can block the cytopathic effect of coronavirus in cell culture and prevent the activation of the inflammatory response caused by the virus (Murmanskiy Vestnik, 2020, March 28).

The information offered by the journalist is difficult to assimilate; to understand it, special knowledge or additional information is required. Its virality is low.

And the information from the article "V Murmanskoj oblasti na samoizolyacii iz-za koronavirusnoj infekcii nahoditsya pochti 100 chelovek" [Almost 100 people are in self-isolation in the 
Murmansk region due to coronavirus infection] will be extremely viral, since it contains a story about an Irish resident who came to Murmansk to participate in a chess tournament and has previously tested positive for coronavirus, but the diagnosis was not confirmed. The article also says that the Murmansk region is on high alert by the decree of Governor Andrei Chibis (Murmanskiy Vestnik, 2020, March 16).

The opinion that the virality of information and its readiness to become viral depends on whether it is positive or negative is not so unambiguous. Both positive and negative information becomes viral. It seems that the reason is rather the recognition, easy digestibility of information.

\section{Conclusion}

A viral information pandemic is developing. The reasons why information becomes viral, as our research has shown, are its content and ways of distribution. For example, the so-called "shuttle path" is currently important, according to which social networks are sources of information for traditional media, whose opinions in publications then return to social networks, where users discuss the problem, including in the form of comments on the publication on the Internet. Another important reason why information becomes viral is its content, that is, its easy digestibility, recognition. This quality of information is also associated with social networks, because the user recognizes the information, as it is already constantly appearing on the Internet. The virality of information depends not so much on how negative it is, but on how relevant it is, in demand, meets the interests and needs of users in the present period. Media that use viral information become interesting for readers, viewers and listeners, not only by the interactivity of the content, but also by its content, which contributes to the formation of audience's trust in the media.

\section{References}

Dabezha, V. V. (2019). Fenomen virusnoj informacii v sovremennyh setevyh SMI [The phenomenon of viral information in modern online media] [Doctoral Dissertation]. Voronezh.

Flew, T. (2021). Trusting and valuing news in a pandemic: Attitudes to online news media content during COVID-19 and policy implications. Journal of Digital Media \& Policy, 12(1), 11-26. https://doi.org/10.1386/jdmp_00045_1

Huxford, J. E., \& Hopper, M. K. (2020). Reporting with emotion: A comparison of journalists' engagement in emotional labour across media types. Journal of Applied Journalism \& Media Studies, 9(1), 39-60. https://doi.org/10.1386/ajms_00010_1

Jenzen, O., Erhart, I., Eslen-Ziya, H., Korkut, U., \& McGarry, A. (2021). The Symbol of Social Media in contemporary Protest: Twitter and the Gezi Park Movement. Convergence. The International Journal of Research into New Media Technologies, 27(2), 414-437. https://doi.org/10.1177/1354856520933747

Kazun, A. D., \& Kazun, A. P. (2020). Volnovaya (de)problematizaciya: osveshchenie pandemii koronavirusa v Rossii na federalnom telekanale [Cyclic (De)Problematization: Coverage of the Coronavirus Pandemic in Russia on a Federal TV Channel]. Monitoring of Public Opinion: Economic and Social Changes Journal (Publis Opinion Monitoring), 6, 284-306. https://doi.org/10.14515/monitoring.2020.6.1754

Kolokytha, O., \& Rozgonyi, K. (2021). From social distancing to digital un-distancing: The COVID-19 pandemic and new challenges for digital policy in the cultural and audio-visual sectors. Journal of Digital Media \& Policy, 12(1), 177-184. https://doi.org/10.1386/jdmp_00054_7

Larsson, A. O. (2020). Facebook as a 'trusted space of everyday communication': Parties, citizens and direct representation. Journal of Applied Journalism \& Media Studies, 9(2), 127-146. https://doi.org/10.1386/ajms_00019_1 
Murmanskiy Vestnik [Murmansk Bulletin] (2020, March 16). V Murmanskoj oblasti na samoizolyacii izza koronavirusnoj infekcii nahoditsya pochti 100 chelovek [Almost 100 people are in self-isolation in the Murmansk region due to coronavirus infection]. https://www.mvestnik.ru/newslent/nasamoizolyacii-iz-za-koronavirusnoj-infekcii-nahoditsya-pochti-100-chelovek/

Murmanskiy Vestnik [Murmansk Bulletin] (2020, March 28). V Rossii sozdali lekarstvo ot koronavirusa [A cure for coronavirus has been created in Russia]. https://www.mvestnik.ru/newslent/v-rossiisozdali-lekarstvo-ot-koronavirusa/

Nigmatullina, K. R. (2021). Mesto social'nyh setej v razvitii regional'noj zhurnalistiki v Rossii [The Role of Social Networks in the Development of Regional Journalism in Russia]. Vestnik Moskovskogo universiteta. Seriya 10. ZHurnalistika, 1. https://vestnik.journ.msu.ru/books/2021/1/mestosotsialnykh-setey-v-razvitii-regionalnoy-zhurnalistiki-v-rossii/

Nord-News. RU (2018, September 11). SMI razbirali internet-fejki i privel v primer Murmanskuyu oblast [The media analyzed Internet fakes and cited the Murmansk region as an example]. https://nordnews.ru/news/2018/09/11/?newsid=106282

Reily, S. S. (2020). Why don't US citizens trust professional journalists. Journal of Applied Journalism \& Media Studies, 9(3), 293-305. https://doi.org/10.1386/ajms_00013_1

Richter, A. (2021). Balancing protection of public health and freedom of information in times of COVID19. Journal of Digital Media \& Policy, 12(1), 27-46. https://doi.org/10.1386/jdmp_00046_1

Schlosberg, J., \& Freedman, D. (2020). Opening the gates: Plurality regulation and the public interest. Journal of Digital Media \& Policy, 11(2), 115-132. https://doi.org/10.1386/jdmp_00017_1

Tretyakova, O. V., Salimov, D. M., Sidorova, T. A., Ivanishcheva, O. N., \& Pankratova, M. E. (2019). Regional Mass Media: From Self-Censorchip to Mythmaking. Amazonia Investiga, 8(20), 559567. https://www.udla.edu.co/revistas/index.php/amazonia-investiga/article/view/1491 